\title{
Correction to: Does Horizontal Inequality Matter in Vietnam?
}

\author{
Thi Thu Hoai Dang ${ }^{1}$ (D)
}

Published online: 12 March 2019

(C) UNU-WIDER 2019

\section{Correction to: Soc Indic Res \\ https://doi.org/10.1007/s11205-018-1896-1}

The article Does Horizontal Inequality Matter in Vietnam?, written Thi Thu Hoai Dang, was originally published electronically on the publisher's internet portal (currently SpringerLink) on December 2017 without open access.

With the copyright holders decision to opt for Open Choice the copyright of the article changed on April 2018 to (C) UNU-WIDER 2019, and this book is licensed under the terms of the Creative Commons Attribution-NonCommercial-ShareAlike 3.0 IGO License (https ://creativecommons.org/licenses/by-nc-sa/3.0/igo/), which permits any noncommercial use, sharing, adaptation, distribution, and reproduction in any medium or format, as long as you give appropriate credit to the UNU-WIDER, provide a link to the Creative Commons licence and indicate if changes were made. If you remix, transform, or build upon this book or a part thereof, you must distribute your contributions under the same licence as the original.

The original article can be found online at https://doi.org/10.1007/s11205-018-1896-1.

Thi Thu Hoai Dang

dangthuhoai2004@gmail.com

1 Central Institute for Economic Management (CIEM), 68 Phan Dinh Phung Street, Hanoi, Vietnam 